Peel, J. S. \& Secher, K. in press: A second occurrence of fossiliferous rocks from the Precambrian shield of southern West Greenland. Rapp. Grønlands geol. Unders.

Poulsen, V. 1966: An occurrence of Lower Palaeozoic rocks within the Precambrian terrain near Sukkertoppen. Rapp. Grønlands geol. Unders. 11, p. 26 only.

Scott, B. H. 1977: Petrogenesis of kimberlites and associated potassic lamprophyres from central West Greenland. Unpubl. Ph. D. thesis, Univ. Edinburgh.

Secher, K. 1976: Airborne radiometric survey between $66^{\circ}$ and $69^{\circ} \mathrm{N}$, southern and central West Greenland. Rapp. Grønlands geol. Unders. 80, 65-67.

Secher, K. 1977: Airborne radiometric survey between $63^{\circ}$ and $66^{\circ} \mathrm{N}$, southern West Greenland. Rapp. Grønlands geol. Unders. 85, 49-50.

\title{
Continued 1:500 000 reconnaissance mapping in the Precambrian of the Sukkertoppen region, southern West Greenland
}

\author{
J. H. Allaart, C. R. L. Friend, R. P. Hall, \\ S. B. Jensen and I. W. N. Roberts
}

The reconnaissance mapping programme for the 1:500 000 map sheet Frederikshåb Isblink - Søndre Strømfjord $\left(62^{\circ} 30^{\prime}-66^{\circ} 45^{\prime} \mathrm{N}\right)$, in the Godthåb-Sukkertoppen region that started in 1976 (Allaart et al., 1977), was continued in 1977. This summer's activity was concentrated in the areas between the inner part of Fiskefjord and Taserssuaq, from Taserssuaq to north of Majorqaq and from Søndre Isortoq to Evighedsfjord (fig. 19). Between Fiskefjord and Søndre Isortoq detailed mapping has been carried out by geologists of Kryolitselskabet Øresund A/S during the summers of 1965-1976. The coastal areas have been investigated previously by GGU geologists (Berthelsen, 1960; Noe-Nygaard \& Ramberg, 1961).

The mapping team of five geologists, supported by two Bell G3 helicopters and by the GGU motor cutter $F$. Johnstrup, operated from a base camp at the head of the fjord Kangerdluarssuk, $30 \mathrm{~km}$ north-east of Sukkertoppen.

The reconnaissance mapping programme will be completed in 1978, when the area north of Evighedsfjord as far as latitude $66^{\circ} 45^{\prime} \mathrm{N}$ will be mapped.

\section{Rock units}

Units belonging to the Isua supracrustals, Akilia association (McGregor \& Mason, 1977) and Amîtsoq gneisses (c. 3750 m.y. old) mapped in 1976 in the Godthåbsfjord region (Allaart et al., 1977) have not been recognised in the Sukkertoppen region, except probably in a localised occurrence east of Majorqaq (see R. P. Hall, this report). 

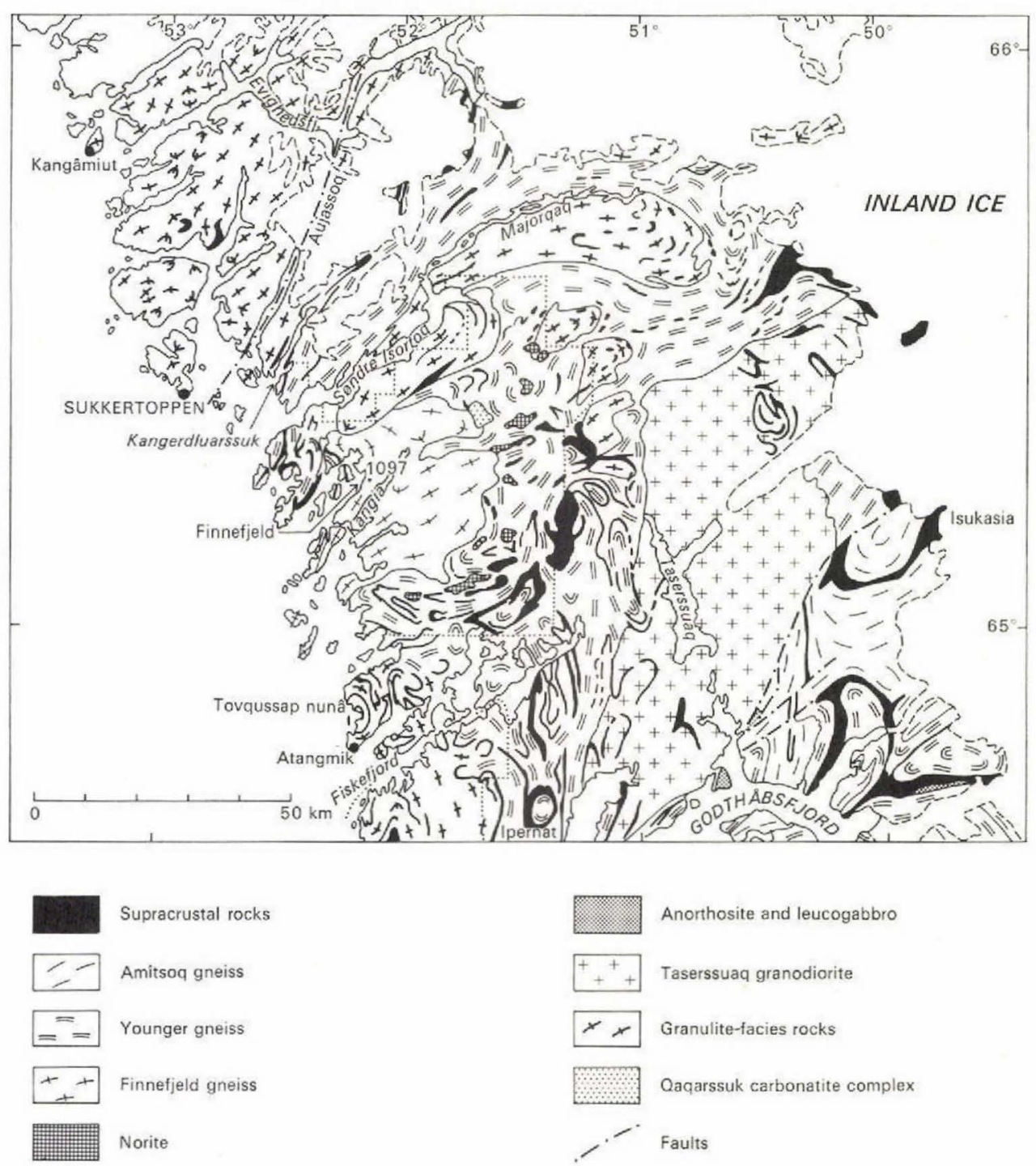

Fig. 19. Geological sketch map of the Sukkertoppen region, southern West Greenland. The areas outlined by the dotted lines have been mapped by geologists of Kryolitselskabet Øresund A/S.

Supracrustal rocks. Rocks of supracrustal origin comprise mainly amphibolite with intercalations of metasedimentary rocks and lenticular bodies of ultrabasic olivine-rich rocks. The amphibolites usually contain clinopyroxene and are often hypersthene-bearing in granulite facies and retrogressed granulite-facies regions. In the metasedimentary rocks garnet and biotite are generally the main mafic minerals whilst sillimanite is of frequent occurrence. Cordierite has been noted in several localities. The supracrustal units form either continuous 
horizons outlining complex fold patterns in the surrounding gneisses, or trains of inclusions which can be followed over considerable distances. In some localities masses of supracrustal rocks are strongly agmatised. The amphibolites, metasedimentary rocks and associated rock types are believed to represent units of Malene-type supracrustals ( $>3000$ m.y. old).

Metamorphosed anorthosites and leucogabbro. Throughout most of the region mapped the amphibolite-facies gneisses as well as the granulite-facies rocks contain trains of inclusions of leucogabbroic and anorthositic rocks. These occasionally preserve relict igneous layering and are considered to belong to the same igneous suite as those of the Godthăb and Fiskenæsset regions.

Amphibolite-facies gneiss. In the north-eastern part of the region mapped, north of the Taserssuaq granodiorite body, quartzo-feldspathic gneisses are the dominant rock type. Compositional banding is often displayed, but in many places the rocks are homogeneous. They vein and agmatise supracrustal and anorthositic rocks. The amphibolite-facies gneisses are thought to represent Nûk gneisses (3000-2800 m.y. old).

Granulite-facies gneisses. Nebulitic hypersthene gneisses are exposed in a large area north of Sukkertoppen (Sukkertoppen granulites of Bridgwater et al., 1976). In some areas very complicated fold patterns exist within continuous zones of supracrustal rocks. In other areas supracrustal and anorthositic rocks occur as trains of fragments or agmatised masses. Black et al. (1973) obtained a combined $\mathrm{Pb}-\mathrm{Pb}$ whole-rock isochron age of $2890 \pm 60 \mathrm{~m}$.y. for a series of samples of granulite-facies gneisses from the Sukkertoppen area and Nordlandet (south of Fiskefjord).

Some large and small areas of granulite-facies gneisses occur in the eastern part of the region mapped around Majorqaq and further to the south. Contacts with the surrounding amphibolite-facies gneisses are usually gradational. Within the amphibolite-facies gneisses basic inclusions usually still contain hypersthene. It is probable that most of the area between Majorqaq and Tovqussap nunâ comprises former granulite-facies gneisses retrogressed under amphibolite-facies conditions.

Taserssuaq granodiorite. This granodiorite, found in 1976 east of the lake Taserssuaq, extends for some distance to the north and west. Due north and east of the lake low-dipping mineral banding is well developed. Moreover, the relations of the numerous basic inclusions indicate a high degree of mobility during the emplacement of the granodiorite, and there is no doubt that the banded granodiorite is of magmatic origin. However, in the north-eastern and south-western parts of the body banding is not developed, but continuous and intricately folded amphibolite zones have been mapped. Apparently the granodiorite there has been formed by in situ homogenisation.

\section{Structural development and metamorphism}

Throughout the region mapped, where homogenisation and/or magmatic mobility have not destroyed marker horizons, complicated structures due to multiple deformation occur and early isoclinal folds, refolded at least twice can be recognised. The structures are similar to those described by Berthelsen (1960) and Lauerma (1964) from Tovqussap nunâ and the Ipernat dome respectively. There are no obvious structural breaks between the Godthåbsfjord and Sukkertoppen regions, and there is no reason to consider important differences in 
the structural and chronological development of the regions. It is therefore probable that the gneisses of the region mapped represent Nûk gneisses and that the deformation and metamorphism took place about 2800 m.y. ago.

The structural relations of the Finnefjeld gneiss (Berthelsen, 1962) suggest that this gneiss body has been emplaced at a relatively late stage during the plutonic development of the area.

Retrogressive metamorphism appears to have been widespread, especially in the area south of Majorqaq and Sukkertoppen where granulite-facies rocks have apparently been downgraded to amphibolite facies. It is possible that most of the Finnefjeld gneiss, now mainly in amphibolite facies, was also under granulite-facies conditions during the metamorphic optimum (Berthelsen, 1962).

\section{Faulting and dyking}

Several generations of dolerite dykes have been described from the region mapped (Berthelsen \& Bridgwater, 1960). South-east of Søndre Isortoq the most conspicuous trends are $\mathrm{N}$ to NNE and NE to ENE (probably the youngest). These may be of the same age as the MD swarms of the Godthåb-Frederikshåb region (Bridgwater et al., 1976).

Northwards from the area around Sukkertoppen, the NNE-trending dykes of the Kangâmiut dyke swarm become increasingly common. The relationships between the Kangâmiut dykes and the other dykes are uncertain.

The NNE-trending Aujassoq fault is a prominent feature in the area of Sukkertoppen granulites with strong mylonitisation in amphibolite facies and retrogression of the surrounding granulites. This fault is possibly related to plutonic events in the Nagssugtoqidian mobile belt further north (Escher et al., 1976).

Most faults are younger than the Aujassoq fault and have NE to ENE trends, showing small dextral displacements with respect to the NNE dolerites.

\section{References}

Allaart, J. H., Jensen, S. B., McGregor, V. R. \& Walton, B. J. 1977: Reconnaissance mapping for the 1:500 000 map sheet in the Godthåb-Isua region, southern West Greenland. Rapp. Grønlands geol. Unders. 85, 50-54.

Berthelsen, A. 1960: Structural studies in the Pre-Cambrian of Western Greenland II. Geology of Tovqussap nunâ. Bull. Grønlands geol. Unders. 25 (also Meddr Grønland 123, 1), 223 pp.

Berthelsen, A. 1962: Structural studies in the Pre-Cambrian of Western Greenland III. Southern Sukkertoppen district. Bull. Grønlands geol. Unders. 31 (also Meddr Grønland 123, 2), 46 pp.

Berthelsen, A. \& Bridgwater, D. 1960: On the field occurrence and petrography of some basic dykes of supposed Pre-Cambrian age from the southern Sukkertoppen district, western.Greenland. Bull. Grønlands geol. Unders. 24 (also Meddr Grønland 123, 3), 43 pp.

Black, L. P., Moorbath, S., Pankhurst, R. J. \& Windley, B. F. 1973: ${ }^{207} \mathrm{~Pb} /{ }^{206} \mathrm{~Pb}$ whole rock age of the Archaean granulite facies metamorphic event in West Greenland. Nature Phys. Sci. 244, 50-53.

Bridgwater, D., Keto, L., McGregor, V. R. \& Myers, J. S. 1976: Archaean gneiss complex of Greenland. In Escher, A. \& Watt, W. S. (edit.) Geology of Greenland, 18-75. Copenhagen: Geol. Surv. Greenland. 
Escher, A., Sørensen, K. \& Zeck, H. P. 1976: Nagssugtoqidian mobile belt in West Greenland. In Escher, A. \& Watt, W. S. (edit.) Geology of Greenland, 74-95. Copenhagen: Geol. Surv. Greenland.

Lauerma, R. 1964: On the structure and petrography of the Ipernat dome, western Greenland. Bull. Grønlands geol. Unders. 46 (also Bull. Comm. géol. Finlande 251), 88 pp.

McGregor, V. R. \& Mason, B. 1977: Petrogenesis and geochemistry of metabasaltic and metasedimentary enclaves in the Amitsoq gneisses, West Greenland. Amer. Miner. 62, 887-904.

Noe-Nygaard, A. \& Ramberg, H. 1961: Geological reconnaissance map of the country between latitudes $69^{\circ} \mathrm{N}$ and $63^{\circ} 45^{\prime} \mathrm{N}$, West Greenland. Geol. Map Grønlands geol. Unders. 1 (also Meddr Grønland 123, 5), 9 pp.

C.R.L.F.,

Department of Geology

Oxford Polytechnic,

Headington,

Oxford $O X 3 O B P$,

U.K.
R.P.H.,

Department of Geology,

Portsmouth Polytechnic,

Burnaby Road,

Portsmouth PO1 3QL,

U.K.
I.W.N.R.,
University College of Wales,
Aberystwyth,
U.K.

\section{Field relations of some Precambrian basic dykes in the vicinity of Sukkertoppen, central West Greenland}

\section{R. L. Friend}

Various field relations of the basic dyke swarms near Sukkertoppen have been described (Ramberg, 1948; Berthelsen \& Bridgwater, 1960; Windley, 1970) and a preliminary chronology suggested (Bridgwater et al., 1976).

The Kangâmiut dykes are noteable in that the central portion of some of the dykes has been converted into amphibolite and garnet amphibolite (Ramberg, 1948; Windley, 1970). Otherwise they appear as normal dolerites.

Within the Sukkertoppen district the most southerly dyke which displays amphibolitisation is that occurring to the north-west of Kistefjeld (fig. 20). Within this dyke the amphibolitised zone was found to be podiform and discontinuous along strike of the dyke, dying out towards en echelon terminations. This relationship was observed in other dykes further north. Therefore the development of the amphibolite is considered to be due to deformation during the emplacement of the dyke (cf. Windley, 1970) and not to multiple intrusion (Bridgwater et al., 1976). Two of the Kangâmiut dykes warrant further description. The first (A) occurs on the northern coast of Hamborgerland (fig. 20). The dyke is about $45 \mathrm{~m}$ wide and displays typical symmetrical zoning from chilled dolerite to garnet amphibolite. At the eastern side of the dyke the schistose zone has suffered later deformation as evidenced by the development of crenulation folds and associated lineation. These structures develop across the schistose fabric and folds or destroy the earlier lineation contained within the schistosity. 